\title{
In Memoriam Dr Claude E. ZoBell
}

Dr Claude Ephraim ZoBell died on March 13, 1989 of cardiac arrest. He is survived by his wife, Jean, 2 sons (Dean and Karl), 11 grandchildren and 11 great-grandchildren. He was born on August 22, 1904, the third of 7 children of Stella Davis and Ephraim Andrew ZoBell in Provo, Utah, and migrated with his family to the Upper Snake River in Idaho. Following his graduation from Southern Idaho College of Education in 1922, he served as a teacher and principal of an elementary school in Rigby, Idaho. After 2 yr, he resigned to continue his education at Utah State University where he received his B.S. and M.S. in bacteriology in 1927 and 1929 respectively. He continued his education, as a Thompson Scholar, at the University of California at Berkeley and San Francisco, receiving his Ph.D. in 1931. His Ph.D. dissertation was on the study of the pathogenic Brucella group of organisms. In 1932 he accepted the position of Instructor in Marine Microbiology at Scripps Institution of Oceanography, changing his area of microbiology completely. He rose through the ranks of Assistant Professor (1936), Associate Professor (1942), Professor (1948), and Professor Emeritus (1972).

During his tenure at Scripps, he served as Assistant to the Director (1936-1952); consultant in epidemiology (1953-1959); member and sometimes chairman, editorial board, Bulletin of the SIO (1945-1960); member, executive committee, Institute of Marine Resources; Chairman, Division of Marine Biology; and on other SIO committees.

He was considered to be the Father of Marine Microbiology. He pioneered research on the effect of microorganisms in relation to the chemical, geological, and biological processes in the ocean, microbial corrosion, petroleum microbiology, adhesion of microbes to surfaces, pressure effects on bacteria, as well as the microbiology of deeps and trenches (including the discovery of barophiles), etc. Many of his scientific discoveries came in an era he termed 'BGG' (before government grants). During the 1930's and 1940's he was the main investigator who kept the field of marine microbiology alive.

His scientific publications number nearly 300 , including the excellent book entitled 'Marine Microbiology' published in 1946. This book still remains the 'Bible' for serious marine microbiologists. He founded the international 'Geomicrobiology Journal' in 1976 and remained its Chief Editor until 1981. For his scien-

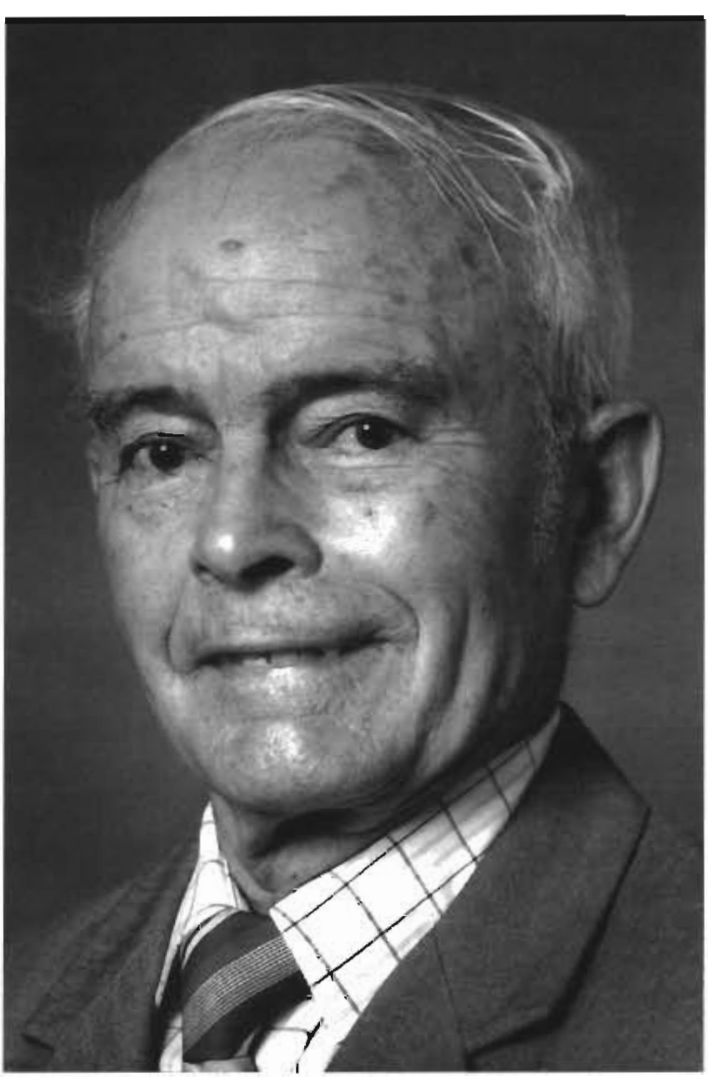

Dr Claude E. ZoBell, Aug 22, 1904 to Mar 13, 1989. Professor Emeritus of Marine Microbiology at Scripps Institution of Oceanography, University of California, San Diego, USA. The photo was taken in Sep 1986

tific accomplishments he received many citations and awards which include the Galathea Medal (by King Frederick IX of Denmark), the citation from the Third World Congress of Petroleum Geologists, the Oceanology Medal of the USR Academy of Science, U.S. Congressional citation for his service to the Petroleum Engineers Environmental Control Development Program, and the Hatai Medal of the Pacific Science Association. Utah State University presented him with the Distinguished Service Award and an honorary D.Sc. He was also retained as a consultant to many companies and corporations, mainly dealing with petroleum, corrosion, and biological products and antibiotics from the sea.

Although he was a member and/or charter member of many scientific and professional societies, he served 
as the first president of the American Society for Limnology and Oceanography (1948-1949), Western Society of Naturalists (1955), and San Diego Society of Natural History. He was also an Honorary member of the Oceanographical Society of Japan, American Society for Microbiology, and Microbiological Society of Thailand. From 1979 to 1987 Claude ZoBell served as Editorial Advisor of 'Marine Ecology Progress Series'.

Throughout his scientific career he was aided by his wife, Jean, who is also a microbiologist. Her loving care and devotion greatly aided the field of marine microbiology.
Dr ZoBell never neglected the nonscientific aspects of society. He devoted much time to the San Diego Society of Natural History, San Diego County Boy Scouts of America, Greater San Diego Science Fairs (1949-1972), Research Council of the San Diego Zoo, Board of Directors of the La Jolla Visiting Nurses Association, etc.

The death of Dr ZoBell, a true pioneer, marks the end of an era in the field of marine microbiology.

Richard Y. Morita

Oregon State University 